\title{
Climate change and deforestation boost post-fire grass invasion of Amazonian forests
}

\author{
Bruno L. De Faria ${ }^{* 1,2}$, Arie Staal ${ }^{3,4}$, Philip A. Martin ${ }^{5}$, Prajjwal K. Panday ${ }^{6,7}$ Andrea \\ D. Castanho ${ }^{8}$ and Vinícius L. Dantas ${ }^{9}$
}

\section{Author affiliations}

${ }^{1}$ Department of Forestry, Federal University of Vales do Jequitinhonha e Mucuri Campus JK, 39100-000, Diamantina, MG, Brazil

${ }^{2}$ Federal Institute of Technology North of Minas Gerais (IFNMG), 39100-000, Diamantina, MG , Brazil

${ }^{3}$ Stockholm Resilience Centre, Stockholm University, Kräftriket 2B, SE-10691, Stockholm, Sweden

${ }^{4}$ Aquatic Ecology and Water Quality Management Group, Wageningen University, P.O. Box 47, 6700 AA Wageningen, the Netherlands

${ }^{5}$ Conservation Science Group, Department of Zoology, University of Cambridge, Downing Street, Cambridge, CB2 3EJ.

${ }^{6}$ Nichols College, Environmental Science, Dudley, MA 01571, United States of America

${ }^{7}$ The George Perkins Marsh Institute Clark University Worcester, MA 01610-1477

${ }^{8}$ The Woods Hole Research Center, 149 Woods Hole Road, Falmouth, MA 025401644, United States of America

${ }^{9}$ Institute of Geography, Federal University of Uberlandia (UFU) - Av. João Naves de Ávila, 2121, Zip Code 38400-902, Uberlandia, Minas Gerais, Brazil.

\footnotetext{
* Corresponding author: blfaria@gmail.com
} 


\section{Climate change and deforestation boost post-fire grass invasion}

\section{of Amazonian forests}

Running head: Post-fire grass invasion of Amazonian forests

Keywords: Amazon, grass invasion, grass-fire cycle, savanna-forest boundaries, regime shifts, tipping points, climate change

\section{ABSTRACT}

Interactions among climate change, deforestation and fires are changing the stability of the Amazon forest, and may promote transitions to degraded grassy ecosystem states. However, our ability to predict the locations in the Amazon that are most vulnerable to these transitions is limited. In this study we used a dynamic carbon model to evaluate how drought, climate change and deforestation could affect the probability of post-fire grass invasion across the Amazon, and identify where grass-fire feedbacks may promote the persistence of species-poor degraded forests with savanna-like structure. Our results suggest that, under current climatic conditions, post-fire grass invasion could affect $11 \%$ of the Amazon, with the south-eastern Amazon at highest risk of invasion. We forecast that under business as usual climate change, by the end of the century areas with a high probability of post-fire grass invasion will increase to $20 \%$ of the Amazon. In $10 \%$ of the Amazon fire return interval will be shorter than the time required for canopy recovery, implying high risk of irreversible shifts to a fire-maintained degraded ecosystem state. Although resilience in canopy regeneration is evident in areas with low fire frequency, increased fire frequency could inhibit regeneration even in forests where grass is currently excluded, and push the Amazon forests towards a tipping point causing large areas of forest to transition to low tree cover state. 
Tropical forests contain between half and two thirds of terrestrial global biodiversity and provide vital ecosystem services at local, regional, and global scales (Dixon et al. 1994; Foley et al. 2007; Marengo et al. 2018). However, these forests are undergoing widespread loss and fragmentation as a result of deforestation as well as degradation from climate change and fire (Hansen et al. 2013; Espírito-Santo et al., 2014). Forests in the tropics are expected to be especially sensitive to such changes. Modeling (Hirota, et al. 2011; Van Nes et al. 2018), observational (Dantas, Batalha, \& Pausas, 2013; Dantas et al. 2016) and experimental (Silverio et al. 2013) studies suggest that a positive feedback between forest loss and fire may cause a shift of closed canopy forest to a grassy savanna-like ecosystem. These novel ecosystems are predicted to differ dramatically in species composition, contain fewer species, and especially fewer endemic species, than both old growth savanna and forest (Veldman \& Putz 2011; Veldman et al. 2015). However, at present, it is unclear how the local process of postfire grass invasion, increasing forest vulnerability to grass-fire feedbacks, could scale-up to affect large forest regions.

One forest region that may face the threat of such a shift to a degraded savanna-like state is the Amazon. This threat is partly driven by a recent sharp increase in fire frequency (from once every 500-1000 years, prior to modern-day human colonization, to once 5-10 years; Barlow \& Peres 2008), due to deforestation and climate change (Balch et al. 2015; Fearnside 2013; Gutiérrez-Vélez et al. 2014). In addition to fire frequency, climate change is predicted to increase fire intensity as a result of reductions in annual rainfall and increases in temperature. These changes in regional climate are expected to increase water deficits reducing litter moisture contents and increasing litter quantity, which will likely promote fires of much higher intensities (De Faria et al. 
2017). Because single high-intensity fires can cause high damage to above-ground plant parts in tropical forests (Brando et al. 2012, 2014), climate change could drive higher forest canopy cover losses after fire events by increasing fire intensity.

In addition to climate change, forest loss and fragmentation may magnify losses caused by fires, as evidence suggests that canopy cover can be reduced by up to $60 \%$ in areas within $3 \mathrm{~km}$ of a forest edge (Broadbent et al. 2008; Wuyts et al. 2017). Combined, the effects of climate change on fire intensity and deforestation in edge areas are expected to result in very high canopy cover losses in the region. As a result, the risk of reaching a critical canopy cover threshold beyond which highly flammable shade-intolerant grasses can establish in the forest understory is expected to increase. (Hoffmann et al. 2012; Silvério et al. 2013; Cardoso et al. 2018). Once this threshold is crossed, both fire intensity and frequency are likely to increase abruptly, as the high cover by low bulk density grass fuels in the understory dramatically increases fuel flammability (Hoffmann et al. 2011). This could potentially create positive fire-grass feedbacks that could cause regime shifts to low tree cover states (Hoffmann et al. 2009; Staver, et al. 2011; Dantas et al. 2016; Van Nes et al. 2018; Staal et al. 2018a). Grass invasion appears to be higher in highly fragmented forests (Balch et al. 2015) and increases in fire intensity resulting from climate change are expected to greatly expand these areas. To avoid being arrested in a fire trap (Murphy et al. 2010; Grady \& Hoffman 2012; Trauernicht et al. 2016), the forest must be resilient, that is, recover canopy cover quickly enough to exclude shade-intolerant flammable grasses before the next fire (Hoffmann et al. 2012). Many studies in both Africa and South America have identified a Leaf Area Index (LAI) of 3 as the critical canopy cover threshold at which shadeintolerant C4 grasses are excluded from the forest understory (Hoffmann et al. 2012, Dantas et al. 2016, Cardoso et al. 2018). How climate change and deforestation will 
affect post-fire grass invasion and the resilience of forests to grass-fire feedback is not currently known.

We simulated grass invasion as a function of canopy cover losses after a fire event (as a function of how climate affects fire intensity) and from logging (within forest edge areas) for a fire taking place under present and future climatic conditions in the Amazon region. We also evaluated the reversibility of grass invasion by contrasting simulated vegetation recovery time (as a function of climate) and fire return interval of a given location. Using this framework, we address the following questions: undermining forest resilience to state shifts.

2. How will predicted increases in fire intensity under climate change and deforestation affect these areas?

3. Where in the Amazon are the least resilient forests that are most likely to shift to a novel ecosystem state with savanna-like structure, under present and future conditions?

We hypothesized that the already drier climate and higher deforestation rates in the south-eastern Amazon (Silva-Junior et al. 2018) would result in high probability of grass invasion and increased fire frequencies in this part of the basin. Since the southeastern region is also predicted to experience increases in temperature and decreases in precipitation under climate change (Chen et al. 2011; De Faria et al. 2017; Phillips et al. 2009), we hypothesized that grass invasion will largely increase in the region, 
$\mathrm{km}^{2}$ of tropical forest. For this study, we used a process-based carbon cycling model,

CARLUC-Fire (De Faria et al. 2017) to simulate the probability of post-fire grass invasion following fire in the Amazon. We used this model to investigate vulnerability

to post-fire grass invasion, both under the current climate and under business-as-usual climate change. Below we outline our study design in detail.

\section{The model}

The CARLUC-Fire model is a modified version of the Carbon and Land Use

Change dynamic carbon model CARLUC (Hirsch et al. 2004) which incorporates forest

144 flammability, fire behaviour, and the impacts of fire (De Faria et al. 2017). The

CARLUC is a process-based, spatially-explicit model and estimates net primary productivity (NPP) based on microclimatic conditions as well as litter, woody debris, and humus resulting from plant mortality (for more detail see supplementary materials). Each time step of the model represents a month.

The CARLUC-Fire model (De Faria et al. 2017) specifically accounts for the effects of fire by estimating forest carbon losses after a fire as a function of fire intensity. CARLUC-Fire uses two loss terms: drought-induced loss of above-ground live carbon stocks and fire-induced loss mediated by changes in fuel loads and moisture. These losses are connected because the former contributes to fuel loads, affecting fire intensity. Thus, climate modulates forest carbon both directly (drought-driven branch and leaf loss) and indirectly (fire-induced post-fire plant mortality, resulting from climate-mediated changes in fire intensity). In this study we adapted the model to predict changes in canopy cover as a function of fire intensity and the associated 
158 probability of grass invasion, and to simulate canopy recovery after a fire (see supplementary materials for details).

\section{Experimental runs}

We ran our simulation under two scenarios: one in which climate mirrored current conditions and one in which climate mirrored a business-as-usual predictions for climate change for the period 2070-2099.

To determine the probability of grass invasion after a fire under current conditions, we ran the model using mean climate conditions for 1980-2009. Climatic conditions were based on the Climatic Research Unit dataset (CRU TS; Harris et al., 2014) and the Integrated Biosphere Simulator (IBIS) dynamic vegetation model, which was forced with the same CRU climate data (Panday et al 2015). Simulated droughts were parameterized using data from NASA's Tropical Rainfall Measurement Mission (TRMM, data product 3B43). Pre-fire canopy cover was based on the MODIS LAI product (MCD15A2H; Mynen et al. 2015). We excluded deforested areas using deforestation maps from the annual Landsat-based Project for Monitoring Amazonian Deforestation (PRODES; INPE, 2017) and MapBiomas collection 3. Following this, we used simulations to estimate the probability that a single fire event in a year of drought would promote grass invasion across the Amazon under current climate (see supplementary materials for more details of methods). invasion, we ran the simulation using a scenario for 2070-2099 based on a

179 Representative Concentration Pathways (RCP8.5 scenario) of the Coupled Model Intercomparison Project Phase 5 (CMIP5) multi-model ensemble. This scenario 
to air temperature increasing by approximately $4-5^{\circ} \mathrm{C}$ across the southern Amazon, and reduced precipitation during the dry season (De Faria et al. 2017; Justino et al. 2011; Phillips et al. 2009). To parameterize this scenario we used air temperature and precipitation projections from 35 climate models participating in the CMIP5. invasion under current and future conditions. Evidence suggests that edge effects can reach 2-3 km from the border, especially logging, which alone can reduce canopy cover by up to $60 \%$ (Broadbent et al. 2008, Wuyts et al. 2017). To simulate the effects of logging on forest edges we imposed an additional $60 \%$ loss in post-fire LAI in areas $\leq 3 \mathrm{~km}$ from the forest border, before calculating the probability of grass invasion. loss. The difference between this and the simulation assuming $60 \%$ loss at the edges was used as a measure of the uncertainty associated with this assumption.

Distance to forest edges was calculated as the distance to a deforestation cell using the "gdistance" packagein R (van Etten, 2017). Deforestation and forest cover were used to define forest borders and were defined using data from PRODES with cumulative deforestation up to 2017. Edge distances were not updated after applying fire-induced losses.

To identify locations that may be vulnerable to being trapped in a grass-fire 
fire interval between 2003-2016. LAI recovery time was calculated as a function of our climate input variables using equations for forest productivity (Hirsch et al. 2004). We considered a forest area to be resilient when the time required to achieve an LAI of 3 return interval per pixel (FRI) was calculated using MODIS Burned Area Product

Collection 6 (MDC64A1; Giglio et al. 2018) and The Global Fire Atlas dataset (Andela et al. 2019). Based on empirical observations for forests and savannas (Dantas et al. 2016) we reduced the mean fire interval by $50 \%$ in areas where LAI values drop below because the relationship between fire probability and climate in South America is nonlinear and complex (e.g. Lehmann et al. 2011).

All analyses of simulations were carried out in R (R Development Core Team, 2012) using the packages rgdal (Keitt et al., 2014), raster (Hijmans et al. 2014), and rasterVis (Perpinan \& Hijmans 2018).

We find that under the current climate (1980-2009), the areas which would show the highest probability of grass invasion if affected by fire are located in the southeastern part and, on a smaller scale, in the southwestern part of the Brazilian Amazon (Acre state) (Fig. 1). These areas cover $560,000 \mathrm{~km}^{2}$, approximately $11 \%$ of the total forest area (Fig. 1A). However, under business-as-usual climate change, the total area with high probability of grass invasion increases to 1.0 million $\mathrm{km}^{2}$ by the end of the century (2070-2099), a $78 \%$ rise. This area amounts to $20 \%$ of Amazonia, most of which is in 
231 change. This results from shifts in local forest LAI (as well as regional-scale modal

232 LAI) towards lower values, increasing the area with an LAI below 3 (Figs. 2 and S3).

233 Climate change alone has a very subtle effect on forest productivity as simulated by the

234 IBIS model (Fig. S3), and, thus, the changes under climate change were mainly

235 explained by changes in fire intensity. Fires increase the area with high probability of

236 grass invasion (LAI < 3) by only $6 \%$ under current conditions, much lower than the 80

$237 \%$ increase under future conditions.

238 Approximately $180,000 \mathrm{~km}^{2}$ of forest patches are within $3 \mathrm{~km}$ from a forest edge (Fig.

239 1C). Accounting for edge effects resulted in an increase in the areas under high risk of

240 grass invasion by $30 \%$, totalling $740,000 \mathrm{~km}^{2}$ (Fig. 1C) and 1.13 million $\mathrm{km}^{2}$ under

241 current and future conditions, respectively (Fig. 1D). In case of the more conservative

242 scenario in which canopy cover losses in edge areas are only $10 \%$ instead of the

243 assumed $60 \%$, grass invasion probability is $17 \%$ lower. 

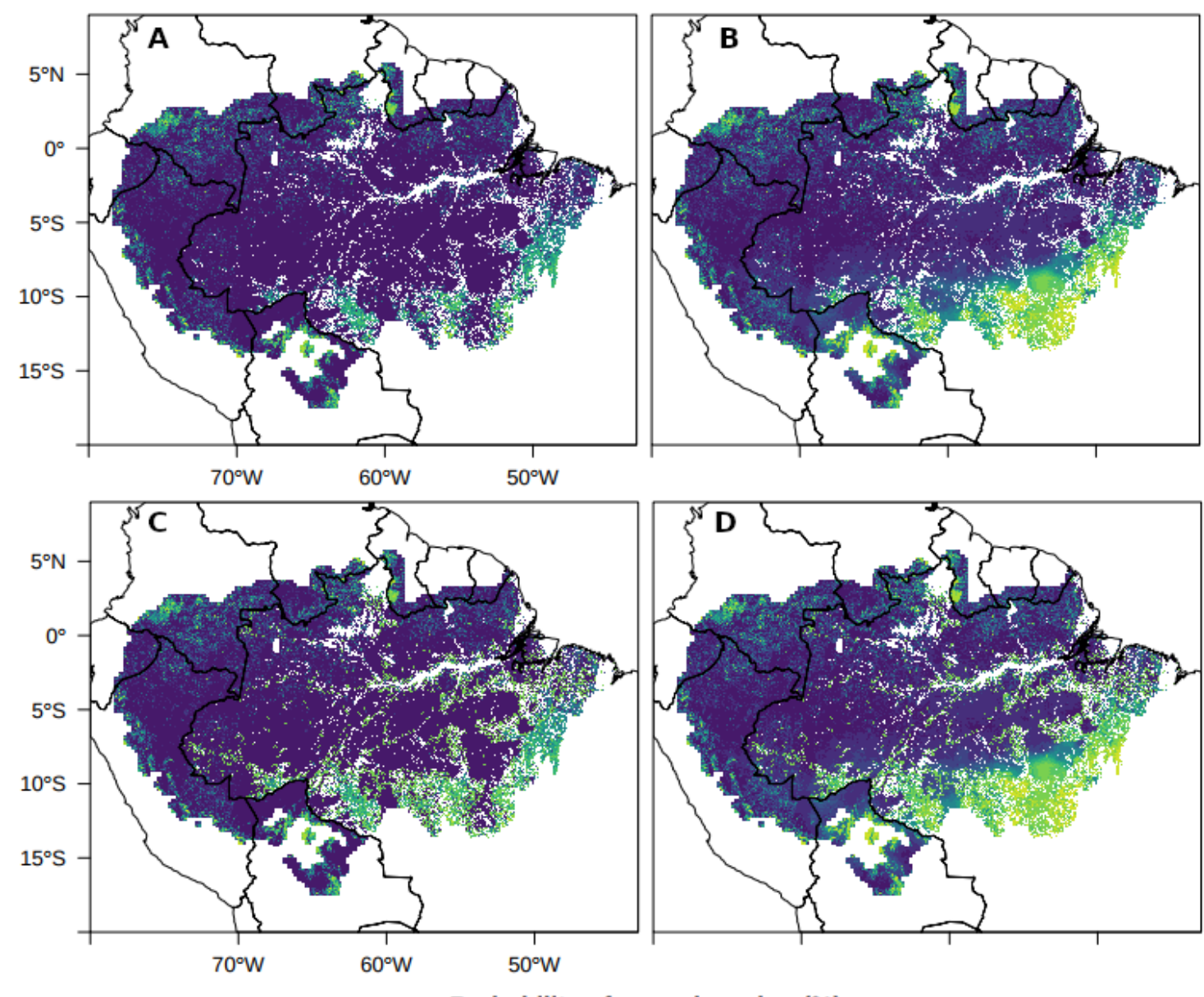

Probability of grass invasion (\%)

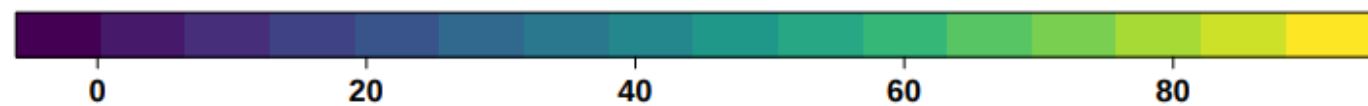

246 Figure 1 - Probability of grass invasion (\%) after fire calculated based on post-fire Leaf

247 Area Index (LAI) and edge effects resulting from deforestation. (A) The probability of 248 grass invasion under current (1980-2009) conditions. (B) The probability of grass 249 invasion under average conditions projected for 2070-2099, in a business-as-usual 250 climate change scenario. (C-D) The probability of grass invasion after fire in A and B, 251 respectively, including edge effects. Our simulations assume fire to take place in a drought year. 
253

254

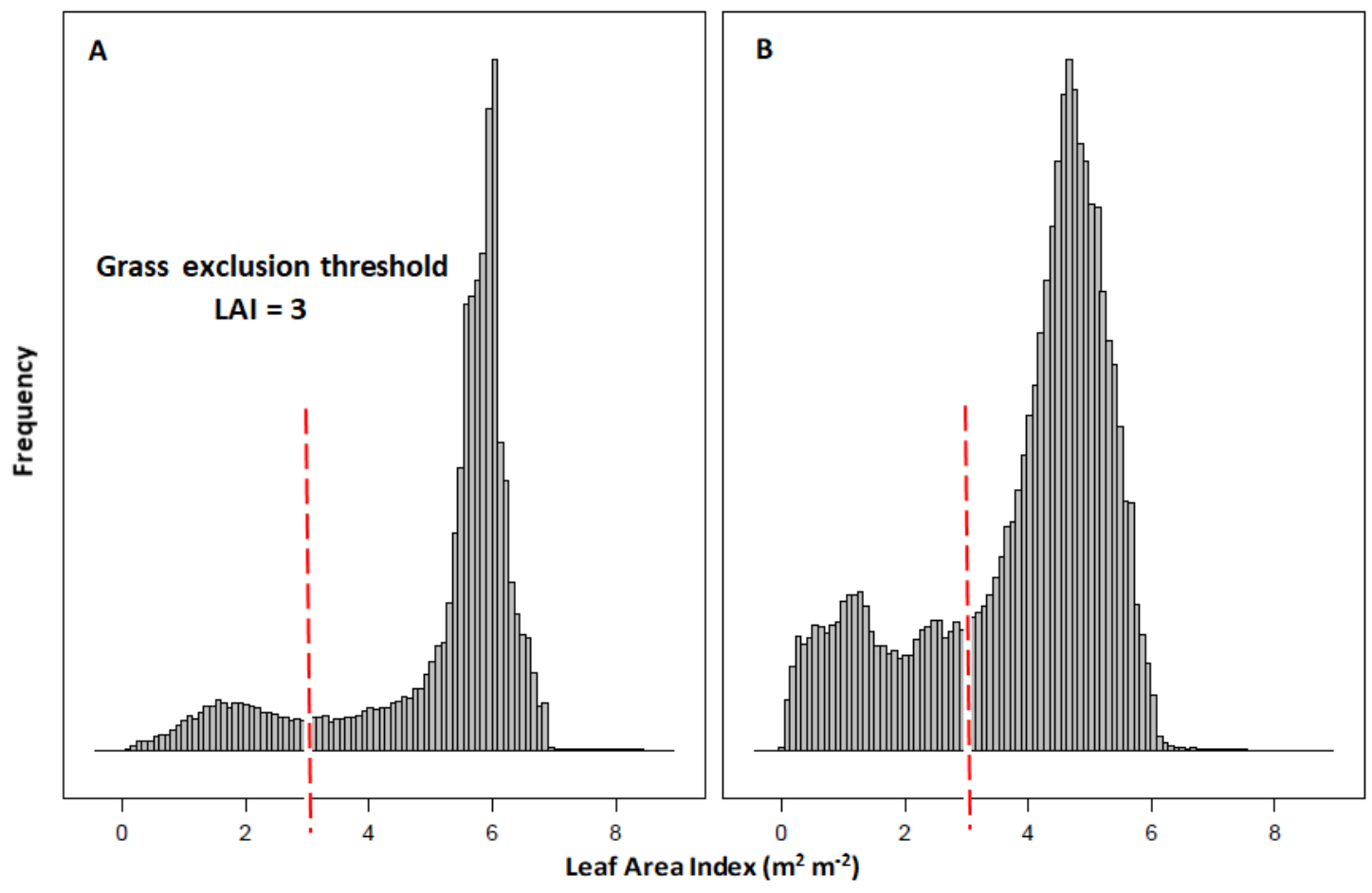

Figure 2 - Frequency distributions of Leaf Area Index (LAI) after a fire for the Amazon region under current (A) and future (B) climate scenarios. Red dashed lines indicate the grass exclusion threshold, the critical LAI value (LAI = 3) above which the forest has sufficient canopy cover to exclude shade-intolerant grasses.

There are substantial spatial differences in recovery time (post-fire time required to achieve LAI =3). The southern and southeastern parts of the basin currently require the longest recovery times $($ mean $=4.6$ years; median $=5.1$ years $)$. In total, an area of $162,000 \mathrm{~km}^{2}$ would require fire intervals longer than five years to achieve an LAI of 3. Climate change doubles this area (Fig. 3B), increasing the area requiring a fire interval longer than 1 year by $52 \%$ in southeastern Amazon (from 659,000 to 1.0 million $\mathrm{km}^{2}$ ). Other areas $\left(244,000 \mathrm{~km}^{2}\right)$ are not substantially affected as the impacts of fire are small and, even when LAI fell below 3, recovery could take place within a year, even in the business-as-usual scenario (Figure 3 A, B). Mean fire return intervals in the Amazon range between 1 and 15 years, and is lowest in human dominated areas (FRI of 1-3 years; Fig. S2), where deforestation and human land uses, especially agriculture, are 
271 in a substantial increase in areas with low fire return interval (Figure S2).
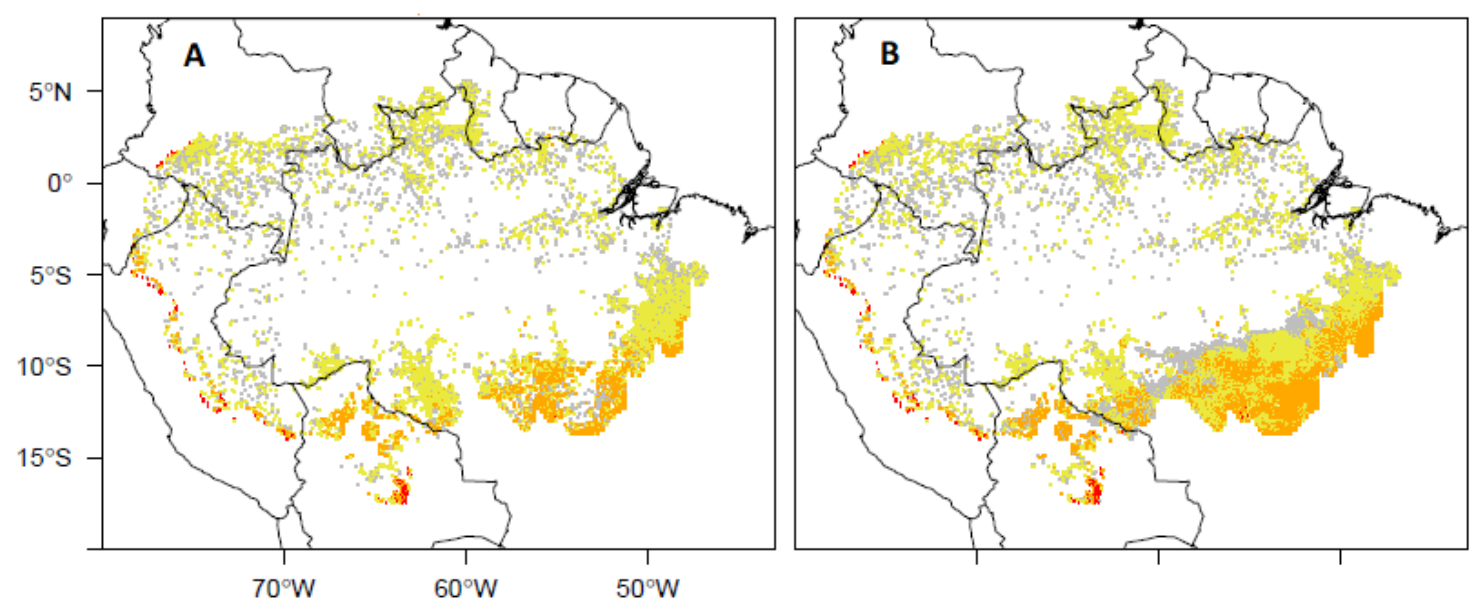

Recovery time (years)

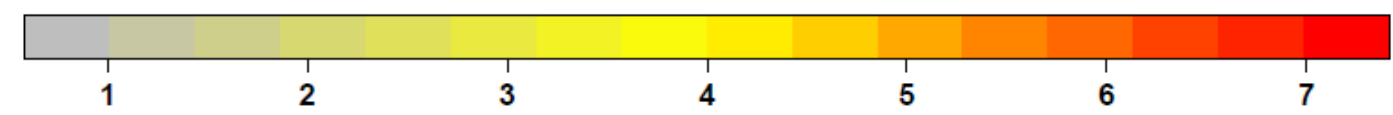

273 Figure 3- Present (A) and future (B) recovery time required for grass exclusion across

274 the Amazon region. Grass exclusion occurs when the forest develops a critical amount of canopy cover (Leaf Area Index = 3) at which shade-intolerant grasses are outcompeted by forest trees.

Non-resilient areas, where recovery time exceeds fire return interval, could emerge in approximately $167,000 \mathrm{~km}^{2}$ under current climate (Fig. 4A), and in about three times this area in the future $\left(449,000 \mathrm{~km}^{2}\right)$ (Fig. 4B). This implies that approximately $10 \%$ of the forest in the Amazon basin may be at risk of a regime shift to a low tree cover state by the end of the 21 st century. 
283

284
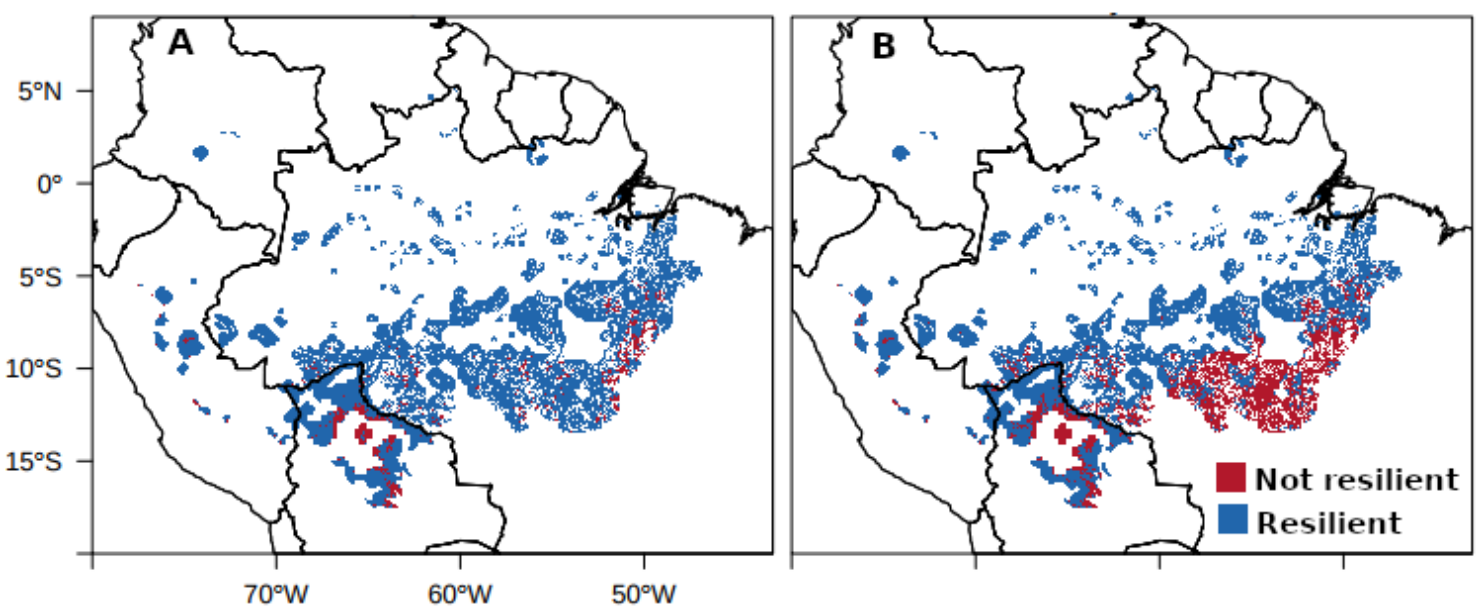

Figure 4 - Resilient and non-resilient forest areas under current (A) and business-asusual climate change (B) conditions. Resilience is based on the difference between the Fire Return Interval (FRI) and forest recovery time. A site is considered resilient (blue) when the time required for the forest to recover an LAI of 3 and exclude shadeintolerant grasses is shorter than the FRI, and not resilient (red) otherwise.

\section{DISCUSSION}

Our model predicted that post-fire grass invasion could affect $11 \%$ of the Amazon under current climatic conditions, which under business-as-usual climate change could rise to $20 \%$ by the end of the century. This implies a dramatic increase in both fire recurrence and intensity in the case a subsequent fire precedes total canopy recovery. The predicted increase under climate change is mostly due to increased fire intensities under future drier and hotter climates, driving greater post-fire canopy cover losses. In both current and future climate, the areas with a high probability of post-fire grass invasion were predicted to be concentrated in the southeastern Amazon, which is consistent with previous empirical studies showing that grass invasion after fire already affects some of these areas (Veldman et al. 2009, Balch et al. 2015). We also found that $3 \%$ of the forest patches in the Amazon were located within $3 \mathrm{~km}$ from an edge, most of which was concentrated in the southeastern region. Edge effects resulting from 
deforestation were predicted to increase the area affected by post-fire grass invasion from 560,000 to $740,000 \mathrm{~km}^{2}$ under present conditions and from 1.0 million to 1.13 million $\mathrm{km}^{2}$ under future conditions, totalling 14 and $23 \%$ of the region. Therefore, we expect that both climate change and deforestation will greatly increase grass invasion in the southeastern Amazon.

Many locations with a high probability of grass invasion currently experience recurrent

fires. This includes areas that are predicted to show the longest recovery periods, many of which require an interval longer than 5 years. This results in a high probability that a subsequent very-high-intensity grass-fueled fire would occur before grass exclusion, driving even larger decreases in LAI (Hoffmann et al. 2012, Silvério et al. 2013, Dantas grasses by reducing tree cover and grasses produce frequent and intense fires (Warman and Moles 2009, Brando et al. 2010, Pausas and Dantas 2017). As a result, the ecosystem would be maintained in a savanna-like state, but with much lower carbon stocks and many fewer species (Veldman and Putz 2011, Veldman et al. 2015) than found in old-growth South American savannas. According to our results, as much as 10 $\%$ of the Amazon, approximately $449,000 \mathrm{~km}^{2}$ (or 449 million hectares), could experience such shifts in the future, which would likely be very difficult to reverse.

The probability of areas being trapped in a grass-fire feedback loop depends on sufficiently frequent fires. Here we used current fire return interval, corrected by increases resulting from grass invasion (see Methods), to predict the areas that could potentially experience irreversible state shifts. However, fire frequencies could also increase in the future due to predicted increases in drought frequency (Aragão et al. 2018). In fact, a recent study predicted that burned area could increase by 39-95\% in the nearby, but more seasonal, savanna region of Brazil, as a result of climate change 
328 (Silva et al. 2019). The extent to which the Amazon will face similar increases is

329 unknown. In addition, several other geophysical feedbacks can take place after grass

330 invasion that could increase fire frequency and preclude a fast forest recovery

331 (Archibald et al. 2018). For instance, canopy cover losses are expected to positively

332 feed back to drought (Staal et al. 2018b), further increasing ecosystem flammability

333 (Staver et al. 2011). Moreover, increased fire frequency is associated with long-term

334 soil nutrient losses (Pellegrini et al. 2018), which could decrease the ability of the

335 vegetation to recover before the next fire (Flores et al. 2019). Synergisms with other

336 disturbances than fire, such as windstorm, could greatly amplify fire-driven mortality

337 and affect recovery, especially in edge areas (Silverio et al. 2017; Brando et al. 2019).

338 Finally, tree regeneration is expected to become much slower once grasses have invaded

339 due to the competition between tree seedlings and grasses (February et al. 2013;

340 Hooper, Legendre, \& Condit, 2005), and frequent fires in grass-dominated ecosystems

341 have been shown to reduce tree growth up to $66 \%$ (Murphy et al. 2010). Predicted

342 increases in atmospheric $\mathrm{CO}_{2}$ concentrations are unlikely to counteract these effects, in

343 part due to the already nutrient-limited nature of most tropical soils (Ellsworth et al.

344 2017). Thus, the area with potential for transitions to alternative ecosystem states could

345 be larger than the conservative estimates shown here.

346 Land-use changes may accelerate the rate of canopy cover reduction by: (i) reducing

347 tree cover and creating vulnerable forest edges (Balch, Nepstad, \& Curran, 2009,

348 Morton et al. 2013); (ii) introducing grass propagules (Veldman \& Putz 2010, 2011);

349 and (iii) increasing ignitions associated with land management practices (Nepstad et al.

350 1999, Cochrane et al. 1999; Armenteras et al. 2013). Logging activities alone currently

351 taking place in edge areas can reduce canopy cover up to $60 \%$ (Broadbent et al. 2008).

352 As we show here, these activities can dramatically increase grass invasion in these 
areas. With $3 \%$ of the forests located within $3 \mathrm{~km}$ from an edge, the Amazon forest already faces a risk of extensive grass invasion under current climatic conditions, and this amount will greatly increase with climate change. Most of these areas are located in the southeastern Amazon. Predicted increases in land-use changes (Aguiar et al. 2016) could make grass invasion similarly likely across other parts of the Amazon region in the future and even increase the probability of fire feedback loops starting in other locations. In fact, since fire frequency and intensity is usually higher in edge areas (Broadbent et al. 2008, Balch et al. 2015, Silva-Junior et al. 2018), the extension of these areas could be greater than estimated here if future fragmentation and land-use changes were considered. Regarding land-use changes, however, fire frequency does not necessarily increase with rising deforestation rates, as the decrease in fuel connectivity also limits fire spread, depending on land use types, resulting in shorter and less frequent fires at the global scale (Andela et al. 2017; Archibald et al. 2013).

Several of the model parameters were derived from a single study in the southeastern Amazon. Therefore, our model did not take into account local factors such as soil and forest types, management history, and flooding and windstorm regimes, when simulating forest recovery time and fire-induced losses. However, these factors likely affect fire-mediated losses and forest resilience. For instance, seasonally flooded forests are less resilient to fire than upland forests due to the rapid loss of soil fertility (Flores et al. 2017). Moreover, trees growing on nutrient rich clay soil can recover faster than plants on white sand nutrient poor soils, and insect herbivores density modulate this effect (Fine, Mesones, \& Coley, 2004). In addition to habitat, forest species traits also vary in space and time, and there are a suite of plant traits that reduce fire (bark thickness, tree size, height, and wood density) and herbivory (e.g. tough and chemically 
378 recovery (e.g. sprouting capacity, fast growth rate; Fine et al. 2004, Hoffmann et al.

379 2009, Balch et al. 2015). Explicitly considering these factors could greatly improve the

380 accuracy of our model. Moreover, climate change is likely to direct affect fire

381 frequency, while our model only considered the indirect effects of climate change, that

382 is, mediated by changes in grass cover, on fire frequency. Evidence shows that grass

383 presence is a key determinant of fire frequency (Dantas et al. 2013). However, it is

384 likely that incorporating the direct effects of climate change on fire frequency in our

385 model could increase the precision of the findings. Finally, our simulations assume fire

386 to take place in a drought year, and evidence shows that fires in wetter year may not

387 drive substantial grass invasions. However, drought events are relatively frequent and

388 are predicted to become more frequent and intense under climate change (Duffy et al

389 2015, Malhi et al 2009). 
In this study, we show that large parts of the southern and southeastern Amazon are at frequent fires to cause a shift to a savanna-like state, and these areas could dramatically increase in response to climate change and fragmentation. Although resilience in canopy regeneration is evident in areas with low fire frequency, increased fire frequency due to climate change, deforestation and fragmentation, as well as the associated feedbacks, could, in many areas, preclude the regeneration of forest cover and push them towards a tipping point, after which they are maintained in a degraded low tree cover state. If such a transition occurred on large scales it would have major impacts for Amazonian biodiversity (Barlow and Peres, 2008), as well as on the ecosystem services provided by the forest at both local and global scales. To avoid these negative impacts, two complementary strategies are required. First, global action to limit greenhouse gas emissions is required in order to reduce the potential for severe climate change. Second, in order to limit anthropogenic fires, we recommend that new protected areas are created, that effective monitoring systems are implemented, and that fire-free agricultural practices are encouraged, especially in the most vulnerable, southeastern, part of the basin. 
425 We thank the Federal Institute of Technology North of Minas Gerais (IFNMG-campus

426 Pirapora and Diamantina), Federal University of Uberlandia (UFU) and Federal

427 University of Vale do Jequitinhonha e Mucuri (UFVJM). We thank A. R. Rech, M. T.

428 Coe, D. Silvério, P. Brando, L. Rattis, E. Pinagé for support and assistance with this

429 research. AS acknowledges support from the European Research Council project Earth

430 Resilience in the Anthropocene (743080 ERA).

431

432

433

434

435

436

437

438

439

440

441

442

443

444

445

446

447

448

449

450

451

452

453

454

455

456

457

458

459

460

461

\section{Author contributions}

Conceptualization: BLF, AS, PAM, VLD.

Participated actively in execution of the study: BLF, AS, PAM, VLD.

Analyzed and interpreted the data: BLF, AS, PAM, VLD.

Data curation: BLF, PkP, ADC.

Visualization: BLF, AS, PAM, VLD.

Writing - original draft: BLF, AS, PAM, VLD.

Supervision: VLD.

Writing - review \& editing BLF, AS, PAM, PkP, ADC, VLD.

1

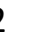

\section{REFERENCES}

Aguiar, A. P. D., Vieira, I. C. G., Assis, T. O., Dalla-Nora, E. L., Toledo, P. M., Oliveira Santos-Junior, R. A., ... \& Nobre, C. A. (2016). Land use change emission scenarios: anticipating a forest transition process in the Brazilian Amazon. Global Change Biology, 22(5), 1821-1840.

https://doi.org/10.1111/gcb.13134

Andela, N., Morton, D. C., Giglio, L., Chen, Y., Van Der Werf, G. R., Kasibhatla, P. S., ... \& Bachelet, D. (2017). A human-driven decline in global burned area. Science, 356(6345), 1356-1362.

https://doi.org/10.1126/science.aal4108

Andela, N., Morton, D. C., Giglio, L., Paugam, R., Chen, Y., Hantson, S., ... \& Randerson, J. T. (2019). The Global Fire Atlas of individual fire size, duration, speed and direction. Earth System Science Data, 11(2), 529-552.

https://doi.org/10.5194/essd-11-529-2019

Aragao, L. E. O., Malhi, Y., Barbier, N., Lima, A., Shimabukuro, Y., Anderson, L., \& Saatchi, S. (2008). Interactions between rainfall, deforestation and fires during recent 
years in the Brazilian Amazonia. Philosophical Transactions of the Royal Society of London B: Biological Sciences, 363(1498), 1779-1785. https://doi.org/10.1098/rstb.2007.0026

Aragão, L. E., Anderson, L. O., Fonseca, M. G., Rosan, T. M., Vedovato, L. B., Wagner, F. H., ... \& Barlow, J. (2018). 21st Century drought-related fires counteract the decline of Amazon deforestation carbon emissions. Nature communications, 9(1), 536. https://doi.org/10.1038/s41467-017-02771-y

Defining pyromes and global syndromes of fire regimes. Proceedings of the National Academy of Sciences, 110(16), 6442-6447.

https://doi.org/10.1073/pnas.1211466110

Archibald, S., Lehmann, C. E., Belcher, C. M., Bond, W. J., Bradstock, R. A., Daniau, A. L., ... \& Higgins, S. I. (2018). Biological and geophysical feedbacks with fire in the Earth system. Environmental Research Letters, 13(3), 033003. https://doi.org/10.1088/1748-9326/aa9ead

Balch, J. K., Nepstad, D. C., \& Curran, L. M. (2009). Pattern and process: fireinitiated grass invasion at Amazon transitional forest edges. In: Tropical Fire Ecology (pp. 481-502). Springer, Berlin, Heidelberg. https://doi.org/10.1007/978-3-540-77381-8 17

Balch, J. K., Bradley, B. A., D'antonio, C. M., \& Gómez-Dans, J. (2013). Introduced annual grass increases regional fire activity across the arid western USA (19802009). Global Change Biology, 19(1), 173-183.

https://doi.org/10.1111/gcb.12046

Balch, J. K., Brando, P. M., Nepstad, D. C., Coe, M. T., Silvério, D., Massad, T. J., Davidson E.A, Lefebvre P, Oliveira-Santos C, Rocha W \& Cury, R. T. (2015). The susceptibility of southeastern Amazon forests to fire: insights from a large-scale burn experiment. Bioscience, 65(9), 893-905.

https://doi.org/10.1093/biosci/biv106

Barlow, J., \& Peres, C. A. (2008). Fire-mediated dieback and compositional cascade in an Amazonian forest. Philosophical Transactions of the Royal Society of London B: Biological Sciences, 363(1498), 1787-1794. https://doi.org/10.1098/rstb.2007.0013

Bivand, R., Keitt, T. \& Rowlingson, B. rgdal: Bindings for the Geospatial Data Abstraction Library. R package version 0, 8-16 (2014).

Bowman, D. M., Balch, J. K., Artaxo, P., Bond, W. J., Carlson, J. M., Cochrane, M. A., ... \& Johnston, F. H. (2009). Fire in the Earth system. Science, 324(5926), 481484. 
Brando, P. M., Nepstad, D. C., Balch, J. K., Bolker, B., Christman, M. C., Coe, M., \& Putz, F. E. (2012). Fire-induced tree mortality in a neotropical forest: the roles of bark traits, tree size, wood density and fire behavior. Global Change Biology, 18(2), 630641.

Brando, P. M., Balch, J. K., Nepstad, D. C., Morton, D. C., Putz, F. E., Coe, M. T., ... \& Alencar, A. (2014). Abrupt increases in Amazonian tree mortality due to droughtfire interactions. Proceedings of the National Academy of Sciences, 201305499. https://doi.org/10.1073/pnas.1305499111

Brando, P. M., Paolucci, L., Ummenhofer, C. C., Ordway, E. M., Hartmann, H., Cattau, M. E., ... \& Balch, J. (2019). Droughts, Wildfires, and Forest Carbon Cycling: A Pantropical Synthesis. Annual Review of Earth and Planetary Sciences, 47, 555581.

Broadbent, E. N., Asner, G. P., Keller, M., Knapp, D. E., Oliveira, P. J., \& Silva, J. N. (2008). Forest fragmentation and edge effects from deforestation and selective logging in the Brazilian Amazon. Biological Conservation, 141(7), 1745-1757. https://doi.org/10.1016/j.biocon.2008.04.024

Cardoso, A. W., Oliveras, I., Abernethy, K. A., Jeffery, K. J., Lehmann, D., Edzang Ndong, J., ... \& Malhi, Y. S. (2018). Grass species flammability, not biomass, drives changes in fire behaviour at tropical forest-savanna transitions. Frontiers in Forests and Global Change, 1, 6. https://doi.org/10.3389/ffgc.2018.00006

Chen, Y., Randerson, J. T., Morton, D. C., DeFries, R. S., Collatz, G. J., Kasibhatla, P. S., ... \& Marlier, M. E. (2011). Forecasting fire season severity in South America using sea surface temperature anomalies. Science, 334(6057), 787-791. https://doi.org/10.1126/science.1209472

Cochrane, M. A., Alencar, A., Schulze, M. D., Souza, C. M., Nepstad, D. C., Lefebvre, P., \& Davidson, E. A. (1999). Positive feedbacks in the fire dynamic of closed canopy tropical forests. Science, 284(5421), 1832-1835.

https://doi.org/10.1126/science.284.5421.1832

Cochrane, M. A., \& Barber, C. P. (2009). Climate change, human land use and future fires in the Amazon. Global Change Biology, 15(3), 601-612. https://doi.org/10.1111/j.1365-2486.2008.01786.x

Dantas, V., Batalha, M. A., \& Pausas, J. G. (2013). Fire drives functional thresholds on the savanna-forest transition. Ecology, 94(11), 2454-2463. $\underline{\text { https://doi.org/10.1890/12-1629.1 }}$

Dantas, V. D. L., Hirota, M., Oliveira, R. S., \& Pausas, J. G. (2016). Disturbance maintains alternative biome states. Ecology Letters, 19(1), 12-19. https://doi.org/10.1111/ele.12537 
De Faria, B. L., Brando, P. M., Macedo, M. N., Panday, P. K., Soares-Filho, B. S., \& Coe, M. T. (2017). Current and future patterns of fire-induced forest degradation in Amazonia. Environmental Research Letters, 12(9), 095005. https://doi.org/10.1088/1748-9326/aa69ce

Dixon, R. K., Solomon, A. M., Brown, S., Houghton, R. A., Trexier, M. C., \& Wisniewski, J. (1994). Carbon pools and flux of global forest ecosystems. Science, 263(5144), 185-190. https://doi.org/10.1126/science.1146961

Duffy, P. B., Brando, P., Asner, G. P., \& Field, C. B. (2015). Projections of future meteorological drought and wet periods in the Amazon. Proceedings of the National Academy of Sciences, 112(43), 13172-13177.

Ellsworth, D. S., Anderson, I. C., Crous, K. Y., Cooke, J., Drake, J. E., Gherlenda, A. N., .. \& Tjoelker, M. G. (2017). Elevated CO2 does not increase eucalypt forest productivity on a low-phosphorus soil. Nature Climate Change, 7(4), 279. https://doi.org/10.1038/nclimate3235

Espírito-Santo, F. D. B., Gloor, M., Keller, M., Malhi, Y., Saatchi, S., Nelson, B., ... Phillips, O. L. (2014). Size and frequency of natural forest disturbances and the Amazon forest carbon balance. Nature Communications, 5, 3434. https://doi.org/10.1038/ncomms4434

Fearnside, P. M. (2013). Climate change as a threat to Brazil's Amazon forest. International Journal of Social Ecology and Sustainable Development (IJSESD), 4(3), $1-12$. https://doi.org/10.4018/jsesd.2013070101

February, E. C., Higgins, S. I., Bond, W. J., \& Swemmer, L. (2013). Influence of competition and rainfall manipulation on the growth responses of savanna trees and grasses. Ecology, 94(5), 1155-1164. https://doi.org/10.1890/12-0540.1

Flores, B. M., Holmgren, M., Xu, C., van Nes, E. H., Jakovac, C. C., Mesquita, R. C., \& Scheffer, M. (2017). Floodplains as an Achilles' heel of Amazonian forest resilience. Proceedings of the National Academy of Sciences, 114(17), 4442-4446. https://doi.org/10.1073/pnas.1617988114

Flores, B. M., Staal, A., Jakovac, C. C., Hirota, M., Holmgren, M., \& Oliveira, R. S. (2019). Soil erosion as a resilience drain in disturbed tropical forests. Plant and Soil, in press. https://doi.org/10.1007/s11104-019-04097-8

Fine, P. V., Mesones, I., \& Coley, P. D. (2004). Herbivores promote habitat specialization by trees in Amazonian forests. Science, 305(5684), 663-665. 


\section{https://doi.org/10.1126/science.1098982}

Foley J.A., Asner G.P., Costa M.H., Coe M.T., DeFries R., Gibbs H.K., Howard E.A., Olson S., Patz J., Ramankutty N. (2007). Amazonia revealed: forest degradation and loss of ecosystem goods and services in the Amazon Basin. Frontiers in Ecology and the Environment 5(1), 25-32.

Gardner, T. A., Barlow, J., Chazdon, R., Ewers, R. M., Harvey, C. A., Peres, C. A., \& Sodhi, N. S. (2009). Prospects for tropical forest biodiversity in a human-modified world. Ecology Letters, 12(6), 561-582. https://doi.org/10.1111/j.1461-0248.2009.01294.x

Gibbs H.K., Ruesch A.S., Achard F., Clayton M.K., Holmgren P., Ramankutty N., Foley J.A. 2010 Tropical forests were the primary sources of new agricultural land in the 1980s and 1990s. Proceedings of the National Academy of Sciences 107(38), 16732-16737. https://doi.org/10.1073/pnas.0910275107

Giglio, L., Boschetti, L., Roy, D. P., Humber, M. L., \& Justice, C. O. (2018). The Collection 6 MODIS burned area mapping algorithm and product. Remote Sensing of Environment, 217, 72-85.

https://doi.org/10.1016/j.rse.2018.08.005

Grady, J. M., \& Hoffmann, W. A. (2012). Caught in a fire trap: recurring fire creates stable size equilibria in woody resprouters. Ecology, 93(9), 2052-2060.

https://doi.org/10.1890/12-0354.1

Gutiérrez-Vélez, V. H., Uriarte, M., DeFries, R., Pinedo-Vásquez, M., Fernandes, K., Ceccato, P., ... \& Padoch, C. (2014). Land cover change interacts with drought severity to change fire regimes in Western Amazonia. Ecological Applications, 24(6), 1323-1340. https://doi.org/10.1890/13-2101.1

Hansen, M. C., Potapov, P. V., Moore, R., Hancher, M., Turubanova, S. A. A., Tyukavina, A., ... \& Kommareddy, A. (2013). High-resolution global maps of 21stcentury forest cover change. Science, 342(6160), 850-853. https://doi.org/10.1126/science.1244693

Higgins, S. I., Bond, W. J., \& Trollope, W. S. (2000). Fire, resprouting and variability: a recipe for grass-tree coexistence in savanna. Journal of Ecology, 88(2), 213-229. https://doi.org/10.1046/j.1365-2745.2000.00435.x

Hijmans, Robert J., and Jacob van Etten. "raster: Geographic data analysis and modeling." R package version 2.8 (2014). 
Hooper, E., Legendre, P., \& Condit, R. (2005). Barriers to forest regeneration of deforested and abandoned land in Panama. Journal of Applied Ecology, 42(6), 11651174. https://doi.org/10.1111/j.1365-2664.2005.01106.x

Hirota, M., Holmgren, M., Van Nes, E. H., \& Scheffer, M. (2011). Global resilience of tropical forest and savanna to critical transitions. Science, 334(6053), 232-235. https://doi.org/10.1126/science.1210657

Hirsch, A. I., Little, W. S., Houghton, R. A., Scott, N. A., \& White, J. D. (2004). The net carbon flux due to deforestation and forest re-growth in the Brazilian Amazon: analysis using a process-based model. Global Change Biology, 10(5), 908-924. https://doi.org/10.1111/j.1529-8817.2003.00765.x

Hoffmann, W. A., Adasme, R., Haridasan, M., T. de Carvalho, M., Geiger, E. L., Pereira, M. A., ... \& Franco, A. C. (2009). Tree topkill, not mortality, governs the dynamics of savanna-forest boundaries under frequent fire in central Brazil. Ecology, 90(5), 1326-1337. https://doi.org/10.1890/08-0741.1 feedbacks at savanna-forest boundaries. Austral Ecology, 37(6), 634-643.

Hoffmann, W. A., Geiger, E. L., Gotsch, S. G., Rossatto, D. R., Silva, L. C., Lau, O. L., ... \& Franco, A. C. (2012). Ecological thresholds at the savanna-forest boundary: how plant traits, resources and fire govern the distribution of tropical biomes. Ecology Letters, 15(7), 759-768. https://doi.org/10.1111/j.1461-0248.2012.01789.x

Houghton, R. A. (2005). Aboveground forest biomass and the global carbon balance. Global Change Biology, 11(6), 945-958. https://doi.org/10.1111/j.1365-2486.2005.00955.x

INPE. Instituto Nacional de Pesquisas Espaciais. Monitoramento da cobertura florestal da Amazônia por satélites - Sistema PRODES-Digital. 2017.

Justino, F., De Mélo, A. S., Setzer, A., Sismanoglu, R., Sediyama, G. C., Ribeiro, G. A., ... \& Sterl, A. (2011). Greenhouse gas induced changes in the fire risk in Brazil in ECHAM5/MPI-OM coupled climate model. Climatic Change, 106(2), 285-302. https://doi.org/10.1007/s10584-010-9902-X

Lewis, S. L., Brando, P. M., Phillips, O. L., van der Heijden, G. M., \& Nepstad, D. (2011). The 2010 Amazon drought. Science, 331(6017), 554-554. https://doi.org/10.1126/science.1200807

Malhi, Y., Aragão, L. E., Galbraith, D., Huntingford, C., Fisher, R., Zelazowski, P., ... $\&$ Meir, P. (2009). Exploring the likelihood and mechanism of a climate-change- 
induced dieback of the Amazon rainforest. Proceedings of the National Academy of

Malhi, Y., Gardner, T. A., Goldsmith, G. R., Silman, M. R., \& Zelazowski, P. (2014). Tropical forests in the Anthropocene. Annual Review of Environment and Resources, 39, 125-159. https://doi.org/10.1146/annurev-environ-030713-155141

MapBiomas Project. Collection 3 of Brazilian Land Cover \& Use Map Series. Available online: http: //mapbiomas.org/pages/database/mapbiomas_collection (accessed on 14 January 2019)

Marengo, J. A., \& Espinoza, J. C. (2016). Extreme seasonal droughts and floods in Amazonia: causes, trends and impacts. International Journal of Climatology, 36(3), 1033-1050. https://doi.org/10.1002/joc.4420

Marengo, J. A., Souza, C. A., Thonicke, K., Burton, C., Halladay, K., Betts, R., \& Soares, W. R. (2018). Changes in climate and land use over the Amazon Region: current and future variability and trends. Frontiers in Earth Science, 6, 228. https://doi.org/10.3389/feart.2018.00228

Morton, D. C., Defries, R. S., Randerson, J. T., Giglio, L., Schroeder, W., \& Van Der Werf, G. R. (2008). Agricultural intensification increases deforestation fire activity in Amazonia. Global Change Biology, 14(10), 2262-2275. https://doi.org/10.1111/j.1365-2486.2008.01652.x

Morton, D. C., Le Page, Y., DeFries, R., Collatz, G. J., \& Hurtt, G. C. (2013). Understorey fire frequency and the fate of burned forests in southern Amazonia. Philosophical Transactions of the Royal Society of London B: Biological Sciences, 368(1619), 20120163. https://doi.org/10.1098/rstb.2012.0163

Murphy, B. P., Russel-Smith, J., \& Prior, L. D. (2010). Frequent fires reduce tree growth in northern Australian savannas: implications for tree demography and carbon sequestration. Global Change Biology, 16(1), 331-343. https://doi.org/10.1111/j.1365-2486.2009.01933.x

Nepstad, D. C., Verssimo, A., Alencar, A., Nobre, C., Lima, E., Lefebvre, P., ... \& Cochrane, M. (1999). Large-scale impoverishment of Amazonian forests by logging and fire. Nature, 398(6727), 505.

https://doi.org/10.1038/19066

Nobre, C. A., \& Borma, L. D. S. (2009). 'Tipping points' for the Amazon forest. Current Opinion in Environmental Sustainability, 1(1), 28-36.

https://doi.org/10.1016/j.cosust.2009.07.003 
Oliveras, I., \& Malhi, Y. (2016). Many shades of green: the dynamic tropical forestsavannah transition zones. Philosophical Transactions of the Royal Society B: Biological Sciences, 371(1703), 20150308. https://doi.org/10.1098/rstb.2015.0308

Panday P K, Coe M T, Macedo M N, Lefebvre P and de Almeida Castanho A D 2015 Deforestation offsets water balance changes due to climate variability in the Xingu River in eastern Amazonia Journal of Hydrology, 523 822-9 https://doi.org/10.1016/j.jhydrol.2015.02.018

Pellegrini, A. F., Ahlström, A., Hobbie, S. E., Reich, P. B., Nieradzik, L. P., Staver, A. C., ... \& Jackson, R. B. (2018). Fire frequency drives decadal changes in soil carbon and nitrogen and ecosystem productivity. Nature, 553(7687), 194-198. https://doi.org/10.1038/nature24668

Perpinan, L. O. \& Hijmans, R. rasterVis: Visualization methods for the raster package. $\mathrm{R}$ package version 0,45 (2018).

Phillips, O. L., Aragão, L. E., Lewis, S. L., Fisher, J. B., Lloyd, J., López-González, G., ... \& Van Der Heijden, G. (2009). Drought sensitivity of the Amazon rainforest. Science, 323(5919), 1344-1347. https://doi.org/10.1126/science.1164033

Silva, P. S., Bastos, A., Libonati, R., Rodrigues, J. A., \& DaCamara, C. C. (2019). Impacts of the $1.5^{\circ} \mathrm{C}$ global warming target on future burned area in the Brazilian Cerrado. Forest Ecology and Management, 446, 193-203.

https://doi.org/10.1016/j.foreco.2019.05.047

Silva-Junior, C., Aragão, L., Fonseca, M., Almeida, C., Vedovato, L., \& Anderson, L. (2018). Deforestation-induced fragmentation increases forest fire occurrence in central Brazilian Amazonia. Forests, 9(6), 305.

https://doi.org/10.3390/19060305

Silvério, D. V., Brando, P. M., Balch, J. K., Putz, F. E., Nepstad, D. C., OliveiraSantos, C., \& Bustamante, M. M. (2013). Testing the Amazon savannization hypothesis: fire effects on invasion of a neotropical forest by native cerrado and exotic pasture grasses. Philosophical transactions of the Royal Society of London B: Biological Sciences, 368(1619), 20120427

https://doi.org/10.1098/rstb.2012.0427

Silvério, D. V., Brando, P. M., Bustamante, M. M., Putz, F. E., Marra, D. M., Levick, S. R., \& Trumbore, S. E. (2019). Fire, fragmentation, and windstorms: A recipe for tropical forest degradation. Journal of Ecology, 107(2), 656-667.

https://doi.org/10.1111/1365-2745.13076 

Scheffer, M. (2018a). Resilience of tropical tree cover: The roles of climate, fire, and herbivory. Global Change Biology, 24(11), 5096-5109. https://doi.org/10.1111/gcb.14408

Staal, A., Tuinenburg, O. A., Bosmans, J. H., Holmgren, M., van Nes, E. H., Scheffer, M., ... \& Dekker, S. C. (2018b). Forest-rainfall cascades buffer against drought across the Amazon. Nature Climate Change, 8(6), 539. https://doi.org/10.1038/s41558-018-0177-y

Staver, A. C., Archibald, S., \& Levin, S. A. (2011). The global extent and determinants of savanna and forest as alternative biome states. Science, 334(6053), 230-232. https://doi.org/10.1126/science.1210465

Sullivan, M. J., Talbot, J., Lewis, S. L., Phillips, O. L., Qie, L., Begne, S. K., ... \& Miles, L. (2017). Diversity and carbon storage across the tropical forest biome. Scientific Reports, 7, 39102. https://doi.org/10.1038/srep39102

Trauernicht, C., Murphy, B. P., Prior, L. D., Lawes, M. J., \& Bowman, D. M. (2016). Human-imposed, fine-grained patch burning explains the population stability of a firesensitive conifer in a frequently burnt northern Australia savanna. Ecosystems, 19(5), 896-909.

https://doi.org/10.1007/s10021-016-9973-2

Van Nes, E. H., Staal, A., Hantson, S., Holmgren, M., Pueyo, S., Bernardi, R. E., ... \& Scheffer, M. (2018). Fire forbids fifty-fifty forest. PloS one, 13(1), e0191027. https://doi.org/10.1371/journal.pone.0191027

Veldman, J. W., Mostacedo, B., Pena-Claros, M., \& Putz, F. E. (2009). Selective logging and fire as drivers of alien grass invasion in a Bolivian tropical dry forest. Forest Ecology and Management, 258(7), 1643-1649.

https://doi.org/10.1016/j.foreco.2009.07.024

Veldman, J. W., \& Putz, F. E. (2010). Long-distance dispersal of invasive grasses by logging vehicles in a tropical dry forest. Biotropica, 42(6), 697-703. https://doi.org/10.1111/j.1744-7429.2010.00647.x

Veldman, J. W., \& Putz, F. E. (2011). Grass-dominated vegetation, not speciesdiverse natural savanna, replaces degraded tropical forests on the southern edge of the Amazon Basin. Biological Conservation, 144(5), 1419-1429. 
857 Veldman, J. W., Buisson, E., Durigan, G., Fernandes, G. W., Le Stradic, S., Mahy,

858 G., ... \& Putz, F. E. (2015). Toward an old-growth concept for grasslands, savannas,

859 and woodlands. Frontiers in Ecology and the Environment, 13(3), 154-162.

$860 \quad$ https://doi.org/10.1890/140270

861

862

Warman, L., \& Moles, A. T. (2009). Alternative stable states in Australia's Wet

863 Tropics: a theoretical framework for the field data and a field-case for the theory. Landscape Ecology, 24(1), 1-13. 